\title{
Type, Personalisation and Depersonalisation in J.M. Coetzee's Waiting for the Barbarians
}

Adrian Grafe

\section{OpenEdition}

1 Journals

Electronic version

URL: http://journals.openedition.org/ces/283

DOI: $10.4000 /$ ces. 283

ISSN: 2534-6695

Publisher

SEPC (Société d'études des pays du Commonwealth)

\section{Printed version}

Date of publication: 1 April 2018

Number of pages: 23-32

ISSN: 2270-0633

\section{Electronic reference}

Adrian Grafe, "Type, Personalisation and Depersonalisation in J.M. Coetzee's Waiting for the Barbarians", Commonwealth Essays and Studies [Online], 40.2 | 2018, Online since 05 November 2019, connection on 02 April 2021. URL: http://journals.openedition.org/ces/283 ; DOI: https://doi.org/ $10.4000 /$ ces. 283

\section{cc) (†) $९$}

Commonwealth Essays and Studies is licensed under a Licence Creative Commons Attribution - Pas d'Utilisation Commerciale - Pas de Modification 4.0 International. 


\section{Type, Personalisation and Depersonalisation in J.M. Coetzee's Waiting for the Barbarians}

Waiting for the Barbarians (1980) recounts the rebellion of the Magistrate of an Empire frontier outpost against the torture inflicted on those the Imperial administration which

employs him considers as "barbarians." The first-person narration is a strategy enabling the author to personalize the Magistrate whose name he never reveals, above all because through it we are allowed to witness the workings of conscience. The novel is a drama of the opposition between justice and law, and of what happens when men who are supposed to uphold the law in fact neglect justice and abuse their power, themselves becoming worse than "barbarians." Within this complex moral and ethical framework the essay at hand proposes to explore the modalities of personhood as established by Coetzee, and its limits.

J.M. Coetzee summed up Waiting for the Barbarians, six years after the publication of the novel, by saying that it was "about the impact of the torture chamber on the life of a man of conscience" (Doubling the Point 363). ${ }^{1}$ The first part of the statement stresses state oppression; the second part, conscience and human being. The unnamed Magistrate, the novel's main character, is then a "man of conscience." He is, as a man of conscience, a type, and that seems to be enough for Coetzee. His character's conscience, in the author's eyes, defines him sufficiently for him to be denied a name. He is at the same time a man of justice, a man of the law. He describes himself as just "another grey-haired servant of Empire" (Waiting for the Barbarians 16). He does not see himself as anyone special: "I am a country magistrate [...], serving out my days on this lazy frontier, waiting to retire [...]. I have not asked for more than a quiet life in quiet times" (Waiting 8). Ironically, the arrival at the Magistrate's Imperial frontier town of state police officer Colonel Joll, and later Warrant Officer Mandel, brings to an end the Magistrate's "quiet life in quiet times" and the rule of law it is his - and, supposedly, their - very function to ensure.

In order to contextualize the present perspective, it is worth pointing out that although there are no direct references to the notions of type and person in Waiting for the Barbarians, Coetzee does refer to type in two later novels. In The Master of Petersburg, the main character, Dostoyevsky, has an affair with Anna, the landlady of the writer's deceased son, Pavel: "He imagines her as she lies [...] beside her daughter, her eyes open and glistening. She belongs, he realizes for the first time, to a type he has never written into his books" (The Master of Petersburg 133). One type of woman, the one Dostoyevsky is used to, has sensations which are intense but "of the surface," whereas Anna's "type" has sensations "deep within their bodies" (Master 133). From then on, he desires this quality as found in this "type" of woman. Teaching The Prelude, the English professor David Lurie, narrator and protagonist of Disgrace, tries to explain to his class why Wordsworth's discovery of Mont Blanc is disappointing to the poet. It is due to

1. An early version of this article was delivered as a seminar paper at Michael F. Zimmermann's Aesthesis conference on "Type and Person" at Eichstadt Catholic University, in Germany, in July 2014. The author wishes to thank Professor Zimmermann for his inspiration and hospitality on that occasion. Thanks, too, to the editor, Claire Omhovère, and to the two anonymous peer reviewers for their suggestions for improvement. 
the discrepancy between the idea the poet has formed of the mountain and its reality. Lurie tries to explain this discrepancy by drawing an analogy based on the experience of being in love: "Do you truly wish to see the beloved in the cold clarity of the visual apparatus? It may be in your better interest to throw a veil over the gaze, so as to keep her alive in her archetypal, goddesslike form" (Disgrace 22). Lurie goes on to use the phrase "the great archetypes of the imagination" and, just before, in connection with the Wordsworth poem, "the great archetypes of the mind, pure ideas" (Disgrace 22-3). The word "idea" alludes to the Platonic forms which were a staple of English Romantic poetry. Coetzee said of Waiting for the Barbarians: "Why does one choose the side of justice when it is not in one's material interest to do so? The Magistrate gives the rather Platonic answer: because we are born with the idea of justice" (Doubling 394). ${ }^{2}$ While wrestling with the problem of evil in various forms in his writing, Coetzee seems to be displaying here a strong bias in favour of the humanist idea that all human beings are basically good, all the more notable in a writer coming from a country whose history has been so fraught with injustice.

The notion of human beings being born with the idea of justice calls to mind Rousseau's definition of conscience: conscience is an innate principle of justice and virtue, which enables us to judge our own actions and those of others as good or evil (cf. Blay's entry on conscience). The Magistrate is a type, to the extent that he is a man whose function it is in the plot of the novel to embody and to represent the idea of justice. The Magistrate as person is not merely, or rather not primarily, the sum of the different elements which make up his personality - his passionate attempt to discover or reach the essence of the barbarian girl, his interest in archaeology. Rather he manifests the necessity for justice, if it is to have any reality or density at all, to be incarnated in the fallible warp and weft of human being.

At this point one might apply a religious perspective. Among other possible references to this domain, the language with which the Magistrate describes the treatment the Empire's officers inflict on him inevitably recalls the Passion: "I have already died one death, on that tree" (Waiting 125). In its statement of charges against the Magistrate, the Empire accuses him of consorting with a "streetwoman" (83), a term suggestive of prostitution. The Magistrate "anoint[s] [the girl] with exotic oils" (56; also 135, "my perfumes and oils"), starting with her feet, in what he repeatedly calls a "ritual" (for example 41). Such a cluster of Biblical allusions or even pattern of Biblical motifs hints at the possibility of our seeing the Magistrate as a Christ figure, and the barbarian girl, mutatis mutandis, as an avatar of Mary Magdalene (John 12:3: Mary "anoint[s] Jesus' feet" with "expensive perfume"). Conversely the Magistrate is a Magdalene anointing the feet of the barbarian girl as Christ figure. They are both Christ figures crucified by the Empire: the barbarian girl is an innocent, tortured without trial, the magistrate is hung on the tree for his defence of justice.

\section{Mask and Identity}

In the first pages of the novel, the Imperial army has taken some "barbarians" prisoner. As Colonel Joll's first conversation with the Magistrate reveals, the Colonel has already

2. One might compare this statement with one made by Dostoyevsky to another character, Nechaev, in The Master of Petersburg: "You were born with the spirit of justice in you" (Master 183). 
judged the prisoners - an old man and his nephew, a young boy - as guilty of belonging to a larger raiding party, though the Colonel lacks evidence of this and the army have captured the prisoners on their own. The Empire, then, refuses to acknowledge the personhood of the barbarians, if Hegel's idea that personhood involves giving the individual a legal dimension, according to abstract law; Hegel's idea of the person corresponds to that to be found in ancient and medieval philosophy, wherein the person is a subject of right and obligation in the moral and legal order (cf. Blay on "person"). The question of conscience intervenes when the first-person narrator, the Magistrate, uses the legal verb to plead: "I grow conscious that I am pleading for [the prisoners]" (4). The Magistrate is distinctly conscious of his conscience, and his "growing conscious" is part of the process of his becoming a person. He uses the legal verb though his professional role is not to plead for, or against, the accused, but to mete out justice. He tells the Colonel that the prisoners have no reason to be lying when they protest their innocence. Again, when the Magistrate tries to persuade himself he has not heard the screams of pain coming from the room where the Colonel interrogates the prisoners, he tries to justify to himself his hearing nothing, his moral deafness: "I begin to plead my own cause" (5); again the Magistrate expresses himself in specifically legal language (through the use of the verb to plead, and through one meaning of the noun "cause," meaning an individual's case offered at law), as though he were almost wholly identifiable with his professional function.

The narrative has now established the existence of two "causes," the barbarians' and the Magistrate's, as though their causes, if not they themselves, were somehow interdependent. The Magistrate's and the barbarians' fate, along with, possibly, their very respective identities, have become lexically entwined, and perhaps existentially so. At the same time, the Magistrate tries to turn a deaf ear to his own moral deafness. It is an attempt to stifle his conscience, but that attempt is useless - he pleads his own cause because he knows he has behaved unethically by letting the Colonel take the prisoners away for questioning so easily. This weighs on his conscience. It is as though his personhood, dependent on his conscience, were at once affirmed and denied.

Moreover, since Coetzee intended the Magistrate - who has no name to individualize him, despite being an individualized character in many other respects - to be "a man of conscience," he is more of a type than a person. The Magistrate is the type, or at least $a$ type, of the conscientious objector. But every conscientious objector is different: it is his very conscientious objection that makes him most truly a person, that singularizes him. In specific relation to conscience, Geoffrey Hill reflected on the concept of "intrinsic value" (cf. Collected Critical Writings 465-77). Hill lays down an integrated vision of intrinsic value in which opposites are somehow complementary and not only antagonistic: "the intrinsic value of our self-realization in and through conscience [stems] directly from the implicated nature of our strength and frailty." Hill takes the verbal adjective "implicated" from a phrase of John Henry Newman's quoted a few lines before: "the human race is implicated in some terrible aboriginal calamity" (Collected Critical Writings 475). This is Newman's "phrase for the inheritance of Original Sin," as Hill calls it (Collected Critical Writings 475). Although Coetzee does not use the term "sin" in Waiting for the Barbarians, he does go out of his way to suggest that it underpins the Magistrate's own worldview: "we are fallen creatures" (Waiting 139). 
Hill's anthropology, while theologically contextualized, is founded upon the primacy of conscience, as a means to what he calls "self-realization." So if we apply this line of reasoning to the Magistrate, we can assert that, because of his conscience, and in spite or because of his moral frailty, the Magistrate is a person, a "self." "Ironically, the nameless Magistrate remains an absence throughout the novel," Hania Nashef has argued, going on to say, "The jargon which has [...] ruled his life, the language through which he has spoken, has left him empty" (Politics of Humiliation 10). Yet this is an incomplete reading of the Magistrate rather than an untrue one. Waiting for the Barbarians is the story of a man whose conscience comes into conflict with the régime which governs him (and of which he is a part). The régime's many disputes with the Magistrate and the various punishments that it metes out to him go to show that the Magistrate is to Joll, Mandel and the other officers an awkward presence, a thorn in the Empire's side, despite his age and apparent ineffectuality.

The Magistrate's narrative shows him to have a powerful reflexivity, an indestructible self-awareness. This is arguably and precisely what the other "servants of Empire" in the novel - Joll, Mandel, the warrant officer - do not have. The Magistrate, then, is not exactly an absence in himself but rather a person who happens to be without self-importance, an ageing civil servant who wants only a quiet life and the freedom to devote himself to his sensual pleasures and few harmless hobbies. He has not spent his professional life waiting for the barbarians, or waiting for anyone or anything - until the barbarians arrive in the shape of the state police who represent his employer, the Empire, and wield authority over him. Coetzee has made the point that the Magistrate's thinking cannot be ascribed to him alone, since his thoughts represent "voices of authority speaking through him" (White Writing 133). Even if for this reason his personhood is incomplete (on condition that one accepts Coetzee's own interpretation of his character), it is the coming of the barbarians - both Colonel Joll and the barbarian prisoners - which makes him a person, or more fully a person. The more he resists the state police by defending the barbarians, the more they acknowledge him, the more he follows the dictates of his conscience, the more he becomes a person. He has his own personal authority deriving not from his Magistrature or his "smooth patrician talk" (77), as he knows full well, showing no surprise at Mandel's scornful attitude towards him, but from his ethical and moral standpoint that in turn springs from his conscience.

To the Magistrate, Colonel Joll's shades are his main defining feature. They make him a source of fascination for the Magistrate and the others at the outpost. They function as a mask, and the Colonel seems to be nothing but his persona: no wonder the Magistrate associates both him and warrant officer Mandel spontaneously with the theatre. The question of identity becomes complex once the word "mask" itself enters the Magistrate's narrative. He approaches the boy whom the old man, now dead - presumably at the Colonel's hands - brought with him for medical treatment. The boy pulls back from the Magistrate whose one desire is to comfort and reassure him: doubling his point, Coetzee writes: "It has not escaped me that an interrogator can wear two masks, speak with two voices, one harsh, one seductive" (7). The boy does not then see the Magistrate and the Colonel as two different persons, or even as persons at all. He sees them as two faces of a single type: the interrogator. Hence identity remains undifferentiated, and in a sense dependent on the observer as opposed to the subject himself. There are other unsettling parallels between the Magistrate and Joll. Joll's face is "masked by two 
black glassy insect eyes from which there comes no reciprocal gaze" (44). When the Magistrate tries to look Joll in the eye, he only sees himself reflected back.

If there is nevertheless a certain diffuseness attaching to the identity of the Magistrate, it is perhaps because he feels "locked in a configuration in which events are not themselves but stand for other things" (38). Referentiality and signification become unstable, blurred - something that no totalitarian state will tolerate - including human identity itself. Moreover, as the Magistrate becomes more and more ostracized by the state police, and following that by the broader society of townspeople, a certain interchangeability enters the course of events. We may consider such interchangeability from the point of view of identity: "A man sits at my desk in the office behind the courtroom" (76), and later, "Colonel Joll sits behind the desk in my office" (110). Although the idea here is that of replaceability rather than identity, the Magistrate's replacement by servants of the state depicted as evil confirms the Magistrate's intuition when he approaches the boy: that to be a servant of the state is to be evil, whoever you are. To serve the state means to be evil, or to wear the mask of evil, which seems to be the same thing. The Magistrate is "invisible behind the glass" of his window (90), just as Joll is invisible behind his shades. This might suggest that the Magistrate's moral standpoint is thus not quite clear, and indeed he often questions his own motives.

When Colonel Joll appears for the last time in the novel, his party defeated by the barbarians, he is no longer wearing his sunglasses, his mask. This cannot simply be because it is night-time when he and his party pull into the frontier town, since when he tortures the barbarian girl and the other prisoners at the start of the plot, it is at night. But paradoxically, without his sunglasses he is more insubstantial than ever. To the Magistrate looking at Joll through his carriage window, he is just a "faint blur against the blackness" (146). The full sentence reads: "I stare through the window at the faint blur against the blackness that is Colonel Joll." The sentence structure is such that one might almost read the end of the sentence as "the blackness that is Colonel Joll": Joll is reduced to the blackness of the sunglasses he has for once taken off (or lost in the struggle against the barbarians). This "blackness" can perhaps stand as the obverse of the "whiteness" (9) of the snow always associated with the barbarian girl in the Magistrate's dream. Empire has somehow stripped both Joll and the barbarian girl of their own identities.

The word "mask" recurs in the Magistrate's depiction of the first man he finds sitting at his desk: "When he looks at me, as he will in a moment, he will look from behind that handsome immobile face and through those clear eyes as an actor looks from behind a mask" (77). He is a perfect type "with regular teeth and lovely blue eyes," the perfect Aryan male. He is not merely or even primarily a pure racial type: he is a pure product of Empire. Bereft of personality, he is all mask, all surface.

\section{The Intolerable Other}

The Magistrate assumes the barbarian girl whom the Magistrate takes in thinks of Joll as "your friend with the black eyes" (135). The girl herself has "black eyes" (26). The Colonel's black eyes are, in fact, his sunglasses, which act as his mask. Since Joll tortured her around the face and eyes, the girl cannot look another person in the eye. Whenever the Magistrate tries to look her in the eye, she gazes blankly beyond him. Joll has reproduced in the girl his own inability to return another person's gaze. By torturing 
her around the eyes, he has transformed her into a version of himself - in her case, a kind of shadow version of himself. Either he has tortured her in this way because he has seen in her a kind of barbarianism which he knows only too well is within himself; or, conversely, because totalitarianism cannot tolerate the Other, and must somehow replicate itself mimetically. To the girl, Joll's mask is his face, since his dark glasses seem to her to be his eyes. It is as though his mask were his reality. He has no personal identity.

As for the girl's blank gaze, it may stand for the side of her that is unknowable both to Joll and to the Magistrate, however much each of them in his own way may probe her. In the Magistrate's recurrent dream of the children playing in the snow, he always pictures the girl - if her it is - as blank-faced, faceless even: "The face I see is blank, featureless [...] it is not a face at all" (Waiting 37). Because she has no face, she has no mask. In this respect the girl is all reality. The Empire is all pretence, all theatre; the barbarian girl is all reality, she has no depth because she has no surface (no mask), she is all one. The Empire cannot stand her reality, nor that of the Other as a group, the barbarians.

Who exactly is the barbarian girl? What makes this question hard for the reader to answer is the fact that because of the first-person narrative technique, the reader can only encounter her through the narrator's testimony. The latter is not entirely subjective, and conditioned by the fact that, when all is said and done, the relationship between the Magistrate and the barbarian girl is a power relationship in which one of the two partners to that relationship holds all the power, and the other one none. The problem is confounded not only by the sympathy which draws the Magistrate to the girl in the first place, but also by his habit of speculation and sympathetic identification. ${ }^{3}$ He constantly tries to understand her feelings and to see himself as he thinks she might see him. ${ }^{4}$ That said, the girl is an enigma to the Magistrate not inherently because she is a barbarian or because they do not speak each other's language - they manage to communicate rudimentarily in the same language - but because she has been tortured behind closed doors, and has seen her father tortured and killed. The impact on her is to damage if not alter her identity: "Is it she I want or the traces of a history her body bears?" (64). Throughout the text, the Magistrate's terms, especially for people, are constantly synonymous, this multinominal approach reflecting shifting perceptions on the Magistrate's part. Thus the unnamed girl is a "barbarian prisoner" (47), "a beggar, a fatherless child" (56), "a stranger, a visitor from strange parts"; 5 and the Magistrate records - indeed insists on - his "freedom to make of the girl whatever I felt like, wife or concubine or daughter or slave or all at once or none" (78). The relationship the Magistrate has with her also colours her identity as outsiders perceive it: to them, she is "the old man's slut" (63). At the heart of the Magistrate's relationship with the girl is the massage ritual by which the girl, in Grant Hamilton's words, "ceases to be a simple determined function in the territorial assemblage of the Magistrate and becomes the constitutive element of the social assemblage of courtship" (On Representation 67). The idea of the "determined

3. The novelist went on to develop an approach to the ethics of sympathy in "The Lives of the Animals," chapters 3 and 4 of Elizabeth Costello.

4. The Magistrate is struck by the girl's "ordinariness," while acknowledging that "she may have ways of finding me ordinary too" (56).

5. An echo of the Biblical "stranger in a strange land" theme (Ex. 2: 22, and elsewhere). As belonging to a nomadic people, the girl could even be a type of the wandering Jew, confronted with a totalitarian state of which the Magistrate himself is willy-nilly a representative. The Magistrate says to Colonel Joll, preparing to ride out against the barbarians: "You and I are strangers - you even more than I" (11). As the Magistrate quite sees, strangers are by definition strangers to each other. The girl is a stranger to him just as he, as the coloniser, is a stranger to her (in her land). 
function in the territorial assemblage" is interpretable as that of a type, while the second half of Hamilton's sentence provides an analogy of person, although the language used is rather cold and tends to reification of the person in both cases. Courtship would seem to turn the girl into a person. When she gets the chance to speak "the pidgin of the frontier" with other people she becomes "a witty, attractive young woman" (64) - a person, in fact, no longer the barbarian girl the Magistrate knows, or rather tries to get to know on his own terms.

The Magistrate tries to break down the girl's distance from him. Hamilton quotes Deleuze: "What is mine is first of all my distance" (On Representation 65). The massage ritual is an attempt on the Magistrate's part both at healing the girl from the wounds the Empire has inflicted on her, and at breaking down the distance he feels lies between them. But this proves impossible. The Magistrate does not allow the girl any distance, so that she has nothing that is fully hers. She is most fully herself away from him, away from someone who reduces her identity to that of a maimed victim of state terror. The Magistrate only discovers this - apparently - "witty" side of her shortly before parting from her forever. At the moment of leave-taking he tries, as he already has done, "to understand who she really is" (73). But all he can see before him is "a stranger," and there is nothing to suggest that that is all she sees before her: a stranger, too.

\section{Personal Identity as Linked to Relationship: "I-Thou" as "primary word"}

Yet we might examine the relationship between the Magistrate and the barbarian girl a relationship which does, after all, form the heart of the novel - from another standpoint. This would involve setting aside the question of masks as well as that of the Magistrate's preventing the girl from being herself. This would rest on a philosophical consideration of personhood as linked to relationship. In an essay, the novelist explores Martin Buber's idea that the "primary word" is not I but "I-Thou": "This primal relation is, however, lost [...]. Intimations of the lost relation, [the] moments of the Thou [...], strange lyric and dramatic episodes, seductive and magical [...] tearing us away to dangerous extremes [...] shattering security," inspire our efforts to reconstitute again and again the being-with of the primal I-Thou. The I searches for You: in Buber's words, "If Thou is said, the $I$ of the combination $I$-Thou is said along with it" (in Doubling 72). According to Hubbeling, "the I-Thou relationship is very often numbered among the essential relations of a person. [...] [I]t is plausible to say that a man cannot exist without at least some essential relations (to God and/or his fellow men) and that these relations belong to his essence. This 'Thou' can be interpreted in a threefold way: an individual Thou; a collective Thou of a group (a political party, tribe, people, etc.); God" (Hubbeling 9). With regard to the Magistrate, the barbarian girl is the "individual Thou"; his relationship to a "group" - the Empire for which he works - is broken off by his guilt, in the eyes of the Empire, in having consorted with a barbarian girl; and his relationship to God, if he has one, cannot be discerned. ${ }^{6}$

The notion that the Magistrate and the barbarian girl share identity, up to a point, may be highlighted by the etymology of the word "type" as deriving from the Latin

6. Occasional Biblical references - "Truly, man was not made to live alone!” (80, clearly pointing to Gen. 2:18) - do not suffice to make of the Magistrate a religious man. There are also some inconclusive allusions to prayer. 
typus, itself related to the Greek tupos, meaning imprint. The state police torture both characters around the face and leave the same mark. The Magistrate examines the girl's face: "I notice in the corner of one eye a grayish puckering as though a caterpillar lay there with its head under her eyelid [...]. The caterpillar comes to an end, decapitated, at the pink inner rim of the eyelid. There is no other mark" (31). Later, the Magistrate has returned the girl to her people and has undergone torture: "The wound on my cheek [...] is swollen and inflamed. A crust like a fat caterpillar has formed on it. My left eye is a mere slit [...]" (115). The Magistrate and the girl thus share the caterpillar as the residual trace of their torture, and as a sign of their irreducible otherness in relation to the Empire. The mark - the imprint - they share, confirms the link between them, but also the fact that in the eyes of the Empire they are merely types.

We close the novel after witnessing the man of conscience as multiple above all: one might say, able to be multiple because of his oneness, literally, his singularity, which is generated precisely by his being a man of conscience. In fact, his own narrative attributes to him a carnivalesque variety of identities. This alone would, on one level, make him a threat to the established order, even if it is the established order which thrusts some of these identities upon him. He is Magistrate, judge, One Just Man, old man, old woman (the police dress him in women's clothing), a beast, a simple machine, a monkey forced to climb a tree, old clown, barbarian-lover, beggar, archaeologist. Personhood in the case of the Magistrate is linked to marginalization: the Magistrate's being marginalized (stripped of his status and function, punished, tortured, imprisoned, publicly mocked) only serves to deprive him of everything except what truly makes him a person - his conscience. However, this argument itself depends on one's definition of personhood: for Catherine McCall, "Persons are social beings, created and constituted, and found only in society [...]. The individual can exist only as a person [...]. The person is a public construction." (Concepts of Person 13-4). One approves the firmness of this definition, but it leaves out the question discussed above, that of interiority. In order to overcome this objection, with regard to Coetzee's Magistrate at least, one might argue that the Magistrate is never a passive onlooker of the barbarians' plight: his conscience always prompts him to act. McCall's definition can also be set against the attitude of the men, other than the Magistrate, who accompany the barbarian girl back to her people: to the men, the Magistrate asserts, the barbarian girl is "a person of no account" (80). This means she has no social identity, no place in society. She is no one. Despite her anonymity, she is not a person of no account to the Magistrate. He identifies her in a world - the outpost - where she has no identity; or, if he does not identify her, he tries to do so, in his own way. His own identity comes under pressure from his torture and imprisonment at the hands of Empire: "I daily become more like a beast or a simple machine, a child's spinning wheel, for example, with eight little figures presenting themselves on the rim: father, lover, horseman, thief..." (84-5). The Magistrate does not give "eight figures," however, and somewhat changes the children's rhyme which is usually, "Tinker, tailor, soldier, sailor, rich man, poor man, beggarman, thief..." The four terms chosen by the Magistrate apply to him (hence his careful and inventive choice). He is childless. But his relationship to the barbarian girl is, problematically, both that of father - he acts as her protector - and lover. We witness him as rider, both when he hunts and when he takes the girl back to her people on horseback. Once stripped of his dignity as Magistrate, he clearly resembles a beggar. Though he is not literally a thief, his rela- 
tionship with the barbarian girl is complex, and one might perceive him as trying to steal something from her - the secret, perhaps, of her very identity.

\section{To be Human is to... Wait.}

The multiplicity of identities which the Magistrate attributes to himself leads us, in conclusion, to explore the possibilities inherent in the verb in the novel's title. The verb "to wait" (including the variant form "to await") occurs in the novel about two dozen times. The title allows us to take the verb as ontological, definitional: it is the act of waiting that arguably defines identity. In the first chapter, we witness the Magistrate depicting his situation in metaphysical terms: on one of his excursions two miles from his outpost where the Magistrate, as a hobby, excavates ruins he has found there, he says he was "opening [his] senses to the night, waiting for a sign that what lay around [him], what lay beneath [his] feet, was not only sand, the dust of bones, flakes of rust, shards, ash. The sign did not come" (16). Coetzee's Dostoevsky is, as for him, "waiting for a sign," when he hears a dog barking and takes it as somehow linked to his dead son Pavel: "He is waiting for a sign, and he is betting (there is no grander word he dare use) that the dog is not the sign, is not a sign at all, is just a dog among many dogs howling in the night. But he knows too that as long as he tries by cunning to distinguish things that are things from things that are signs he will not be saved" (Master 83). This dimension alone brings together the Magistrate and Coetzee's later recreation of Dostoevsky (along with the shared etymology of magistrate and master). Beyond anonymity, person and type, the act of waiting defines the Magistrate as a human being, since waiting is itself a sign - a sign of the incompleteness of the human being. The "sign" is the equivalent of the Magistrate's "something": "There is something staring me in the face, and still I do not see it" (155). The "sign" for which he is waiting, the "something" staring him in the face, may not be something, but rather - however tendentious it may seem - someone, an Other. And the Magistrate's self-awareness may enable us to conclude that waiting in itself is not a criterion of humanness, since animals wait, too. It is the combination of waiting and knowing one is waiting which makes for humanness. Perhaps what ultimately defines the Magistrate is his writerly identity in tandem with his waiting: he stares "at his empty white paper, waiting for words to come" (58). The text of the novel, then, is proof that his writerly identity and his waiting have been vindicated.

Adrian GRAFE Artois University

\section{Works Cited}

BLAY, Michel, ed. Grand dictionnaire de la philosophie. Paris: Larousse, 2003.

Coetzee, J.M. Waiting for the Barbarians. London: Penguin, 1982.

-. White Writing: On the Culture of Letters in South Africa. New Haven / London: Yale UP, 1988.

-. Doubling the Point: Essays and Interviews. Ed. David Attwell. Cambridge, MA / London, UK: Harvard UP, 1992.

—. The Master of Petersburg. London: Secker \& Warburg, 1994.

—. Disgrace. London: Vintage, 2000.

—. Elizabeth Costello. London: Vintage, 2004. 


\section{commonweaLth EssaYs and studies}

Hamilton, Grant. On Representation: Deleuze and Coetzee on the Colonized Subject. Amsterdam / New York: Rodopi. 2011.

Hill, Geoffrey. "Rhetorics of Value and Intrinsic Value." Collected Critical Writings. Ed. Kenneth Haynes. Oxford: Oxford UP, 2008. 465-77.

Hubbeling, Hubertus G. "Some Remarks on the Concept of Person in Western Philosophy." Concepts of Person in Religion and Thought. Ed. Hans G. Kippenberg, Yme B. Kuiper, and Andy F. Sanders. Berlin / New York: Mouton de Gruyter, 1990. 9-33.

McCald, Catherine. Concepts of Person: An Analysis of Concepts of Person, Self and Human Being. Aldershot: Avebury, 1990.

Nashef, Hania A.M. The Politics of Humiliation in the Novels of J. M. Coetzee. New York / London: Routledge, 2009. 